\title{
Performance of Immobilized Chlorella Algae for Removing pb(II) Ions from Aqueous Solution
}

\author{
Hala N. Abdulkareem and Abeer I. Alwared
}

Environmental Eng. Department, University of Baghdad

\begin{abstract}
This study aims to show the effectiveness of immobilization of Chlorella green algae biomass in the form of bead for the removal of lead ions from synthetic polluted water at various operational parameters such as $\mathrm{pH}(2-6)$, biosorbent dosage (0.5-20 g/L) and initial concentration (10-100 mg/L). More than $90 \%$ removal efficiency was achieved. FTIR and SEM-EDX analysis of the biosorbent before and after sorption show differences in the functional groups on the adsorbent surface. Langmuir and Freundlich equilibrium isotherm, pseudo-first-order and pseudo-second-order kinetic models were applied to the experimental and results and show good conformity with Langmuir isotherm model and pseudo-second-order kinetic model with correlation coefficient $(0.994)$ and (0.998) respectively.
\end{abstract}

Keywords: Lead ions, Chlorella green algae, Biosorption, Immobilization, Isotherm, and kinetic models.

Received on 17/02/2019-, Accepted on 03/04-/2019, published on 30/09/2019

https://doi.org/10.31699/IJCPE.2019.3.1

\section{1- Introduction}

Toxic metal ions removal from wastewater is important in economic and environmental problems. Heavy metals and other metal ions contaminants are aqueous waste streams of many industries, such as mining and tanneries.

Some metals associated or released with these activities are $\mathrm{Pb}, \mathrm{Hg}, \mathrm{Cr}$, and $\mathrm{Cd}$. Some of these metals accumulate in living organisms and cause various diseases and disorders. Metals such as lead, mercury, arsenic, zinc, copper, and cadmium are highly toxic when adsorbed into the body causing accumulative poisoning, brain damage, cancer, and so forth.

Lead is an enzyme inhibitor and general metabolic poison that has the ability to replace calcium in the bone to form sites for long-term release, hence, the need to remove these toxic metals from water and wastewater is a point of interest. Lead permissible limit in wastewater as set by the Environment Protection Agency is $0.1 \mathrm{mg} / \mathrm{L}$, and in drinking water, it is $0.05 \mathrm{mg} / \mathrm{L} \mathrm{[1]}$.

The conventional methods for heavy metals removal include chemical precipitation, electrodialysis, ion exchange, membrane separations, reverse osmosis, and solvent extraction which maybe not effective at low metal concentration and costly so the search for new, effective and economical technique for metal removal from wastewaters has directed attention to biosorption that uses various biological materials at little or no cost to remove heavy metal [2].

Biosorption, describes the removal of heavy metals from aqueous solution by using nonliving biomass.
Biosorption is favorable as an alternative to conventional methods of metal recovery from solutions due to availability and low-cost raw material.

Freely suspended biomass may have better contact with adsorbate during the removal process, suspended biomass maybe not the practical form to the direct use because of many problems, and one of them is the separation of the biomass from the treated water. Immobilization suggested as an easy handling of the biomass, enhance its stability, reusability, mechanical strength, and the ease of separation and regeneration [1].

This study aims to investigate the feasibility of using immobilized chlorella biomass for the removal of lead ions from aqueous solutions. The effects of different experimental parameters, such as initial $\mathrm{pH}$, removal time, dose of sorbent and initial lead concentration on the sorption capacity were studied.

\section{2- Materials and Methods}

\subsection{Sorbents and Contaminant}

The algae used in the experiment were purchased from the buy algae web site (https://www.buyalgae.com/) as a pure dried sample of chlorella in a powdered form. The selected amount of the algal biomass mixed with $2 \%$ sodium alginate solution before that the algae wetted with a specific amount of distilled water, the mixture then dropped in a $5 \% \mathrm{CaCl} 2$ solution left there in the solution for $2 \mathrm{hr}$ to full solidification. The formed beads of diameter $4 \pm 0.1 \mathrm{~mm}$ were washed with distilled water before using in the experiments. 
Lead ions stock solution was prepared by dissolving the known amount of $\mathrm{Pb}(\mathrm{NO} 3) 2$ powder, in a known volume of distilled water different concentrations were prepared by dilution from the stock solution.

Then the $\mathrm{pH}$ of the aqueous solution was controlled using $0.1 \mathrm{M} \mathrm{HCl}$ and $0.1 \mathrm{M} \mathrm{NaOH}$ to the required value. Fig. 1 shows the algae before and after immobilization.

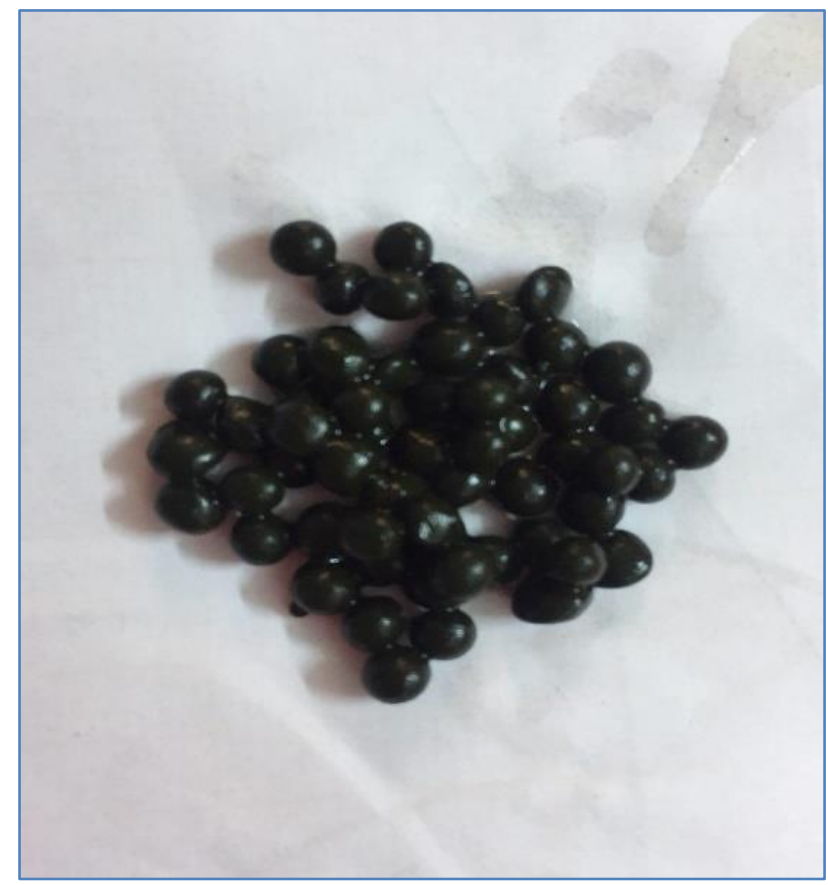

(a)

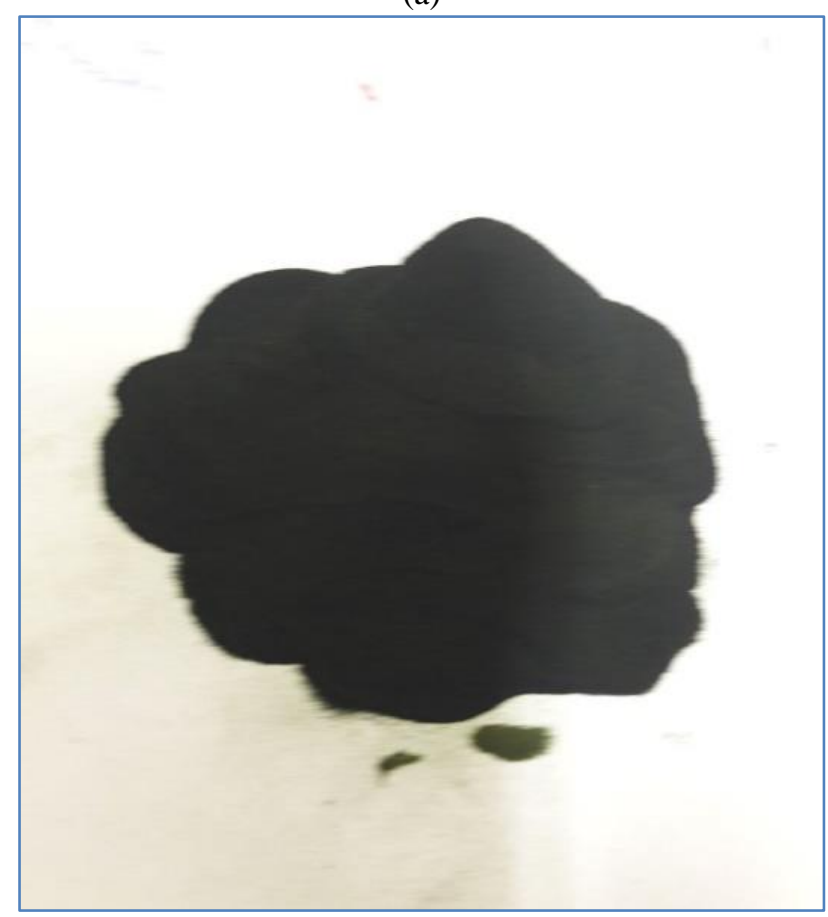

(b)

Fig. 1. Chlorella algae (a) before (b) after immobilization

\subsection{Experimental Work}

$250 \mathrm{~mL}$ conical-flasks were used in the experiments, each flask washed with $\mathrm{HNO}_{3}$ diluted solution then washed with distilled water before starting the experiments. The flasks filled with $100 \mathrm{~mL}$ of $\mathrm{Pb}(\mathrm{II})$ ion solution and selected sorbent amount. In order to do the experimental work, several parameters were studied to examine their effect on the removal process such as $\mathrm{pH}$, contact time, initial metal concentration, agitation speed, and sorbent dose. The agitation of flasks in the form of shaking was done for a defined time using orbital shaker (Edmund Buhler SM25, German). (10 mL) volume of the contaminated solution collected from each flask, without the need for further filtration, solutions analyzed to measure the remaining metal concentration. The measurements of metal ions carried out using atomic absorption spectrophotometer (AAS, Sens AA, Australian) Duplicate measurements of the samples were done for more accurate results. The removal efficiency of contaminants calculated from eq. (1):

$R=\frac{\left(C_{o}-C_{e}\right)}{C_{\mathrm{o}}} \times 100$

Where $C_{o}$ and $C_{e}$ are the initial and equilibrium lead concentrations $(\mathrm{mg} / \mathrm{L})$.

The amount of sorbate adsorbed on the sorbent material, $q_{e}(\mathrm{mg} / \mathrm{g})$, can be determined by:

$q_{e}=\left(C_{o}-C_{e}\right) \frac{\mathrm{v}}{m}$

Where $m$ is the amount of sorbent on the flask $(\mathrm{g})$ and $\mathrm{V}$ is the volume of contaminant solution (L)

\section{3- Results and discussion}

\subsection{Characteristic of Immobilized Beads}

\section{a. FTIR Analysis}

Fourier Transform Infrared (FTIR) spectroscopy was used to identify the functional groups present in the biosorbent. The biomass samples were examined using the FTIR spectrometer (model: FT/IR-4100typeA) within range of $400-4000 \mathrm{~cm}^{-1}$.

Analysis as can be seen in Fig. 2 indicated the broad and strong bands at 3500 to $3000 \mathrm{~cm}^{-1}$ which can be attributed to the overlapping of $-\mathrm{OH}$ and $-\mathrm{NH}$ stretching. The band at 2900 attributed to the $\mathrm{C}-\mathrm{H}$, at 1620 to $1590 \mathrm{~cm}^{-1}$ due to the $\mathrm{C}=\mathrm{O}$, and amide groups, at $1400 \mathrm{~cm}^{-1}$ $\mathrm{N}-\mathrm{H}$ bending in the amine groups, and at $1025 \mathrm{~cm}^{-1}$ to $\mathrm{CO}$ stretching of alcohols and carboxylic acids.

As compared to simple biosorbent, biosorbent loaded with chromium (VI) the broadening of -OH peak at 3440 $\mathrm{cm}^{-1}$ and carbonyl group peak at $1628 \mathrm{~cm}^{-1}$ was observed. This indicates the involvement of hydroxyl and carbonyl groups in the biosorption of metal ions [3]. 


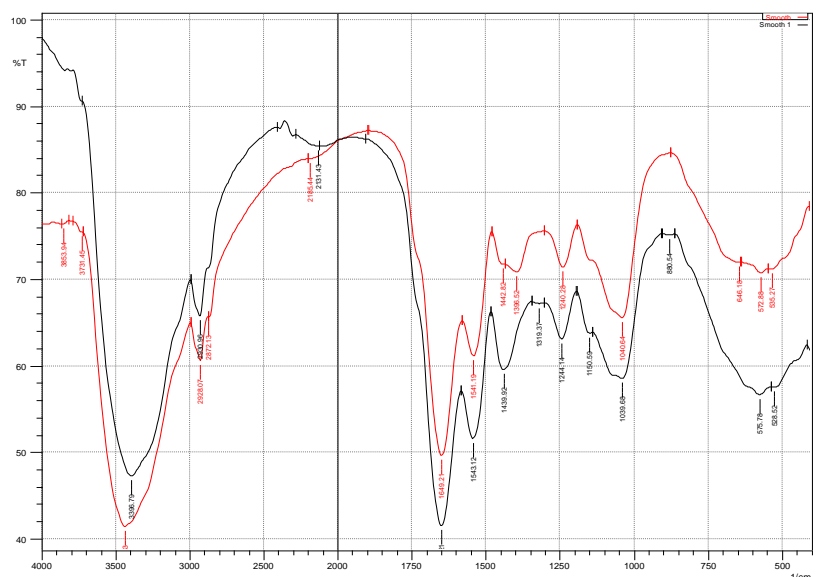

Fig. 2. FTIR of immobilized chlorella black before lead removal red after lead removal

\section{b. SEM-EDX Results}

SEM-EDX result of chlorella algae bead before and after $\mathrm{pb}$ (II) ion deposit on the surface of beads as shown in Fig.3. The EDX also shows the composition of the surface of the alginate bead before and after sorption which indicate that change in light metal on alginate surface which support the theory of ion exchange during the removal process.

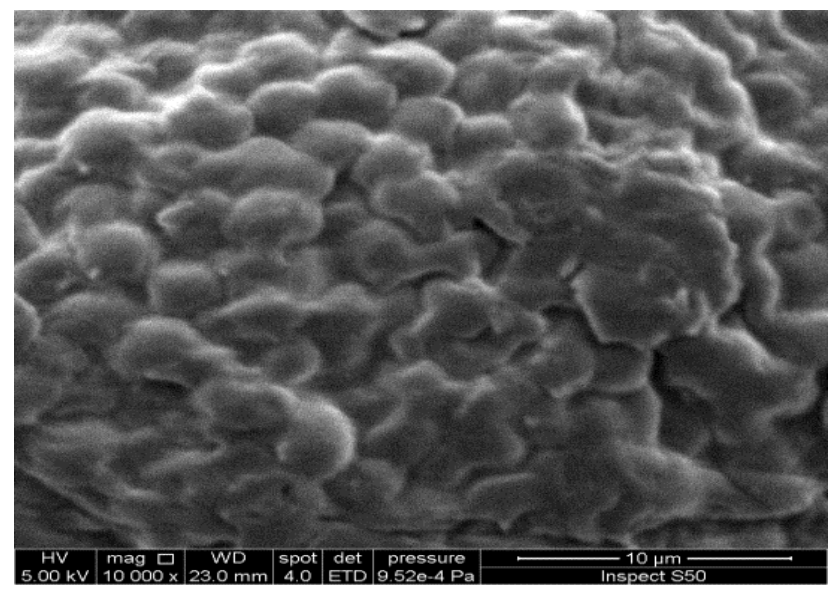

(a)

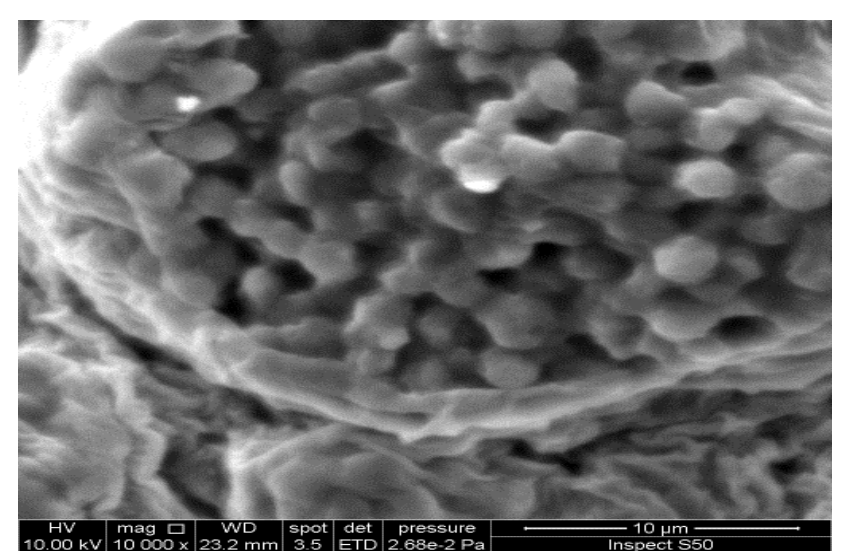

(b)

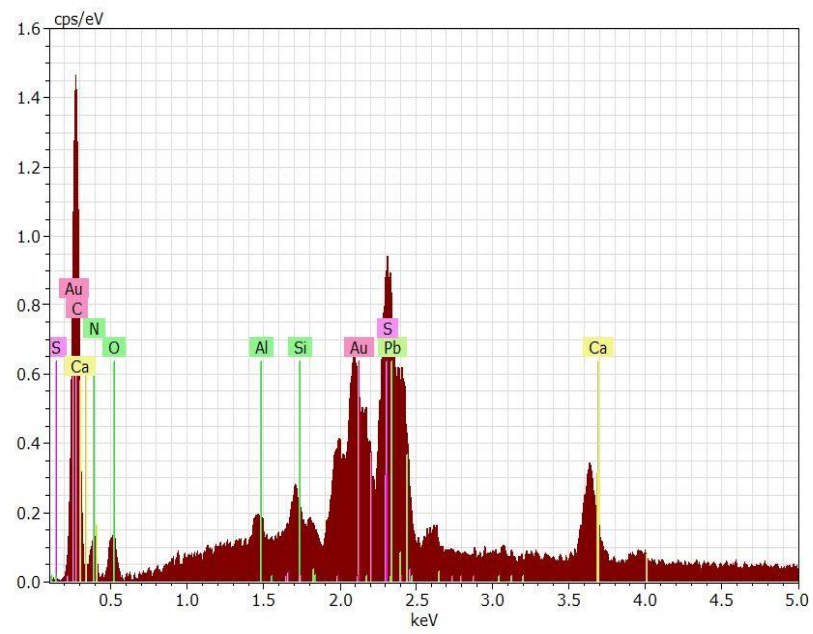

(c)

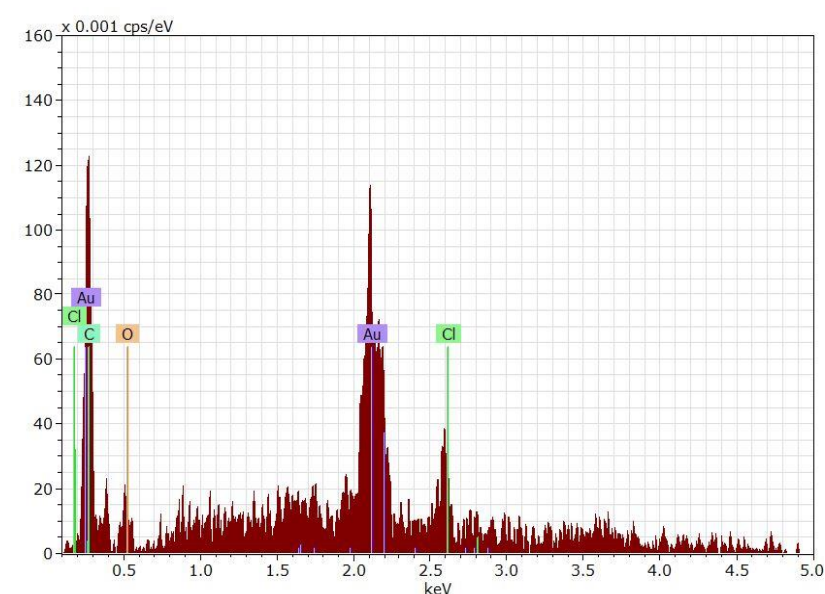

(d)

Fig. 3. SEM-EDX analysis of immobilized chlorella algae A SEM before and B after lead removal C and D EDX before and after lead removal respectively

\subsection{Effect of Different Parameter}

a. $\mathrm{pH}$ of the solution

In the biosorption the initial $\mathrm{pH}$ of the solution is a very important parameter. The effect of this parameter was studied in a pH range, 2-6, and not exceeded 6 to avoid precipitation of heavy metal. Fig. 4 shows removal efficiency variation with the variation of $\mathrm{pH}$ value. At $\mathrm{pH}$ value 2 , the removal efficiency was low due to solution protonation that lower lead ion passing and compete with it.

The removal efficiency starts to increase because functional groups such as carboxyl, phosphate, imidazole and amino groups, would be exposed due to deprotonation and carried negative charges, thus facilitating the biosorption of metal. 
At higher $\mathrm{pH}$ in basic conditions, the amount of $\mathrm{OH}$ ions is increased in the solution, so metal ions react with it and precipitated as a metal hydroxide [4], [5].

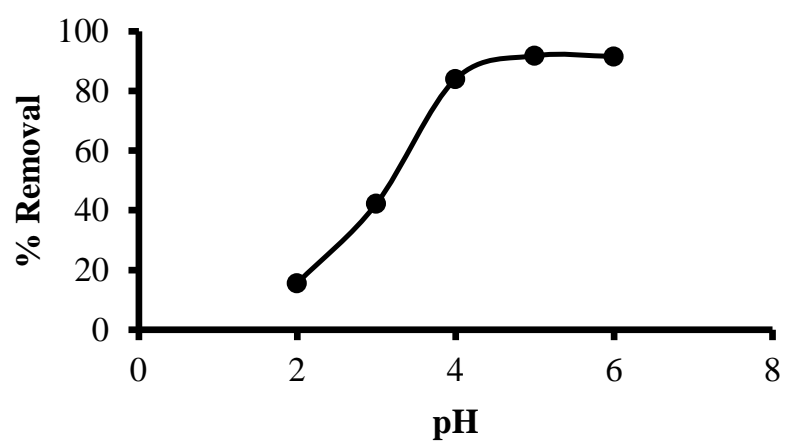

Fig. 4. Effect of $\mathrm{pH}$ on removal process

b. Sorbent Dose

Doses of $(0.05,0.2,0.6,1$ and, $2 \mathrm{gm})$ were used in different flasks with the same conditions to study their effect on the sorption process and the results are represented in Fig.5 .The uptake capacity of the sorbent increased when decreasing biosorbent dosage because of interference between the binding sites on the surface, while increasing sorbent dose more than $1 \mathrm{gm} / 100$, ml the quantity of metal ions uptake decreases because of the sites on the biosorbent surface remain unsaturated during the removal process [6], [7], [8].

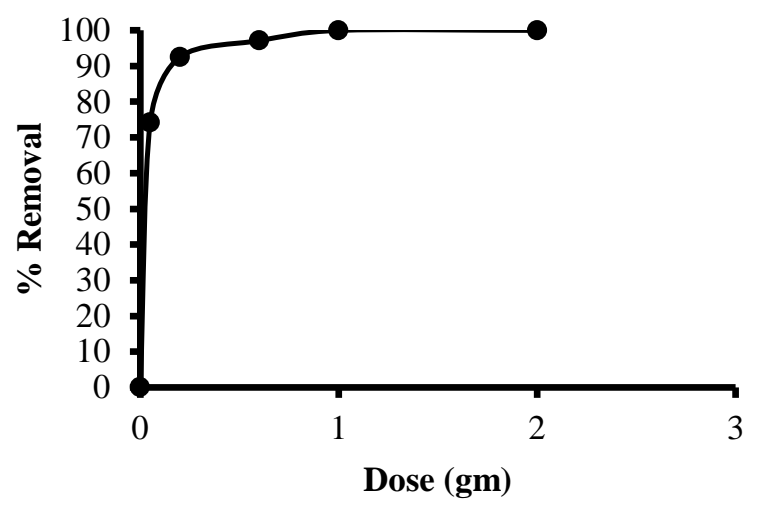

Fig. 5. effect of dose on the removal process

\section{c. Sorption Time}

Fig. 6 presents the removal efficiency of $\mathrm{pb}(\mathrm{II})$ ions during different time periods. It can be seen from this figure that biosorption rate was increased rapidly at the initial stage of time from 0 to 30 and thereafter become nearly constant at around $90 \%$ then gradually the biosorption retarded due to the decrease in biosorption sites on the sorbent surface [9].

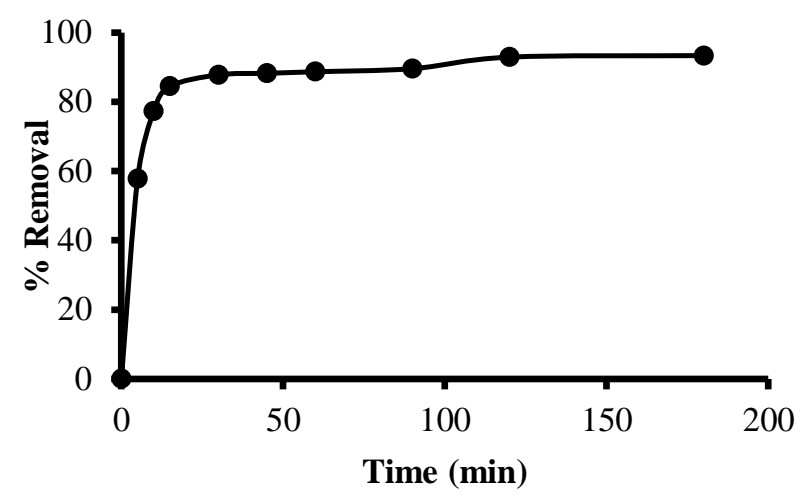

Fig. 6. Effect contact time on the removal process

d. Initial lead Concentration

With increasing initial metal ions concentration the biosorption capacity also increased, high metal ions concentration provides a driving force that overcomes the resistance of the mass transfer layer between the beads and the metal in the solution. Also, the biosorption process enhanced because of the number of collisions between metal ions and biosorbent increases when increasing initial metal concentration. The reduction in metal removal efficiency might be attributed to the insufficient binding sites for adsorption associated with increasing metal concentration, and that the binding was saturated [9], [10] as showed in Fig. 7

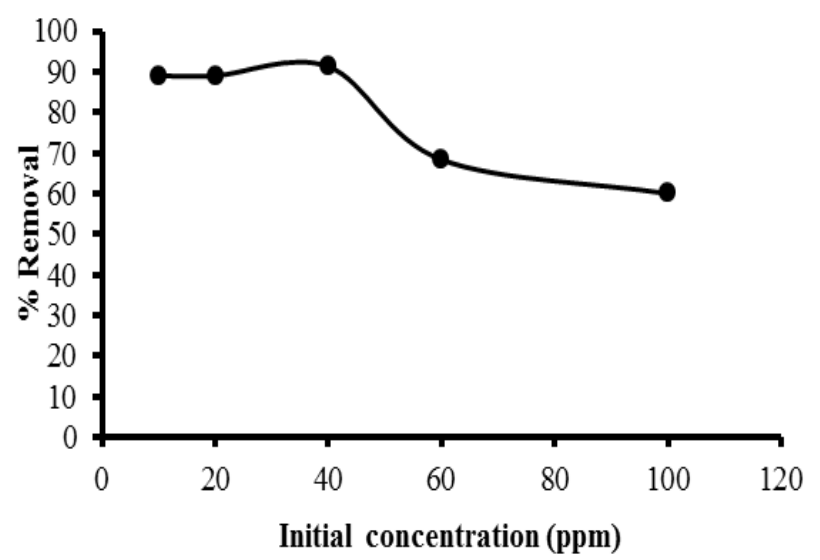

Fig. 7. Effect of initial concentration on the removal efficiency of lead ions

\section{4- Isotherm and kinetic studies}

\subsection{Isotherm}

Desorption isotherm which is the equilibrium relationship at a given temperature were studied by. Langmuir, and Freundlich, Equations are used widely to describe sorption process. The importance of these models is finding the relationship between the sorbed amount of sorbate onto adsorbent $\left(\mathrm{q}_{\mathrm{e}}\right)$ and the concentration of sorbate remaining at equilibrium $\left(\mathrm{C}_{\mathrm{e}}\right)$ in the aqueous solution [11]. 


\section{a. Langmuir model}

This model, suggests that sorption process occurs uniformly on the active sites of the sorbent at the surface, and once a sorbate occupies a site, no further sorption can take place at that site, Langmuir model can be represented as [12]

$q_{e}=\frac{q_{\max } b C_{e}}{1+b C_{e}}$

Where $\mathrm{b}$ and $q_{\max }$, are the Langmuir constants, represent the saturated monolayer sorption capacity $(\mathrm{mg} / \mathrm{g})$, and the sorption equilibrium constant, and refer to the slope of the model.

b. Freundlich model

$q_{e}=k C_{e}^{1 / n}$

Is an empirical Model which suggests that sorption based on multilayer heterogeneous surface given by eq. (4) where $1 / n$ is the intensity of sorption and $k$ is a constant related to the maximum adsorption capacity [13], [14].

\subsection{Sorption Kinetics}

The transformation rate of pollutant from aqueous solution to solid phase [6] and the kinetic in the present study were represented using two models:

a. Pseudo-first order kinetic model

$q_{t}=q_{e}\left(1-\mathrm{e}^{-k_{1} t}\right)$

The $q_{e}$ and $q_{t}$ are the equilibrium and the amount of sorbate removed from the solution at time $t$ respectively in $(\mathrm{mg} / \mathrm{g})$, and $k_{l}$ is the pseudo first order rate constant $(1 / \mathrm{min})$ [15]

b. Pseudo-second order kinetic model

This model can be described as:

$q_{t}=\frac{\mathrm{t}}{\left(\frac{1}{k_{2} q_{e}^{2}}+\frac{t}{q_{e}}\right)}$

Where $\mathrm{k}_{2}$ is the pseudo second order rate constant $(\mathrm{g} / \mathrm{mg}$ $\min )[16]$.

From the experimental results the relationships between the sored quantity (qe, $\mathrm{mg} / \mathrm{g}$ ) and the equilibrium concentration (Ce) for $\mathrm{Pb}$ (II) ions in the solution. The values of the calculated parameters and the correlation coefficients $\left(\mathrm{R}_{2}\right)$ are listed in Table $\mathbf{1}$ and the models are represented in Fig. 8 from the table the high correlation coefficients were found for the Langmuir model which suggested that homogeneous surface of the sorbent with all the sorption sites assumed to have an equal sorbate affinity and the sorption occurs uniformly on sorbent active sites [15].
The Pseudo-second order model gave a better fit based on the $\mathrm{R}_{2}$ values. This indicating that sorption process occurred was chemisorption [16].

Table 1. Constants of isotherm models for sorption of $\mathrm{pb}$ (II) ion onto alginate bead

\begin{tabular}{cccccc}
\hline $\begin{array}{c}\text { Isotherm } \\
\text { model }\end{array}$ & Parameter & value & $\begin{array}{c}\text { Kinetic } \\
\text { model }\end{array}$ & Parameter & value \\
\hline \multirow{2}{*}{ Langmuir } & $q_{\max }(\mathrm{mg} / \mathrm{g})$ & 30.06 & & $q_{e}(\mathrm{mg} / \mathrm{g})$ & 18.42 \\
& $b(\mathrm{~L} / \mathrm{mg})$ & 0.245 & $\begin{array}{c}\text { Pseudo- } \\
\text { first order }\end{array}$ & $k_{l}\left(\mathrm{~min}^{-1}\right)$ & 0.346 \\
& $\mathrm{R}^{2}$ & 0.994 & & $\mathrm{R}^{2}$ & 0.74 \\
& $k(\mathrm{mg} / \mathrm{mg})(\mathrm{L}$ & 7.757 & Pseudo- & $q_{e}(\mathrm{mg} / \mathrm{g})$ & 18. table \\
Freundlich & $/ \mathrm{mg})^{n}$ & & second & $k_{2}(\mathrm{~g} / \mathrm{mg} \min )$ & 0.045 \\
& $n$ & 2.762 & order & $\mathrm{R}^{2}$ & 0.998 \\
\hline & $\mathrm{R}^{2}$ & 0.873 & & & \\
\hline
\end{tabular}

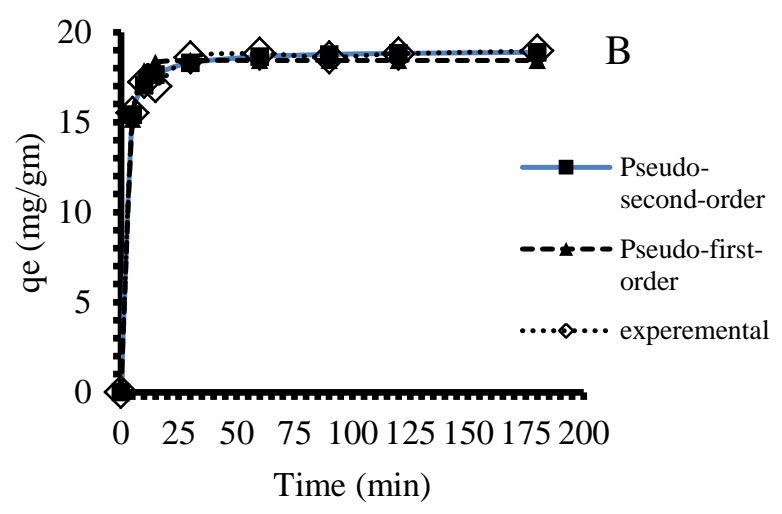

Fig. 8. Isotherms and kinetic models for sorption pb (II) ions onto alginate bead

\section{Conclusions}

A non-conventional bio-carrier of immobilized Chlorella green algal is a good way for lead ions removal from simulated wastewater without losing their ability to adsorb. Different parameters studied and the isotherm shows that. Langmuir isotherm model gives the best fit model for lead ions removal than Freundlich models with the adsorption capacity. The monolayer adsorption capacity of $\mathrm{pb}(\mathrm{II})$ ions calculated from the Langmuir model was found $30.06 \mathrm{mg} / \mathrm{g}$, Pseudo-second order kinetic model gives good fitting to present the process of removal which indicates according to the model controlling mechanism in the removal process is the chemisorption process.

\section{References}

[1] Surisetty, V. R, Kozinski, J., and Nageswara, L.R., "Biosorption of Lead Ions from Aqueous Solution Using Ficus benghalensis L".Journal of Engineering.ID 167518,2013,

[2] Babarinde, N.A.A., Babalola, J.O., and Sanni, R.A., "Biosorption of lead ions from aqueous solution by maize leaf" International Journal of Physical Sciences,vol.1(1) ,2006, pp.023-026. 
[3] Sharma, A. S.; and, Bhalerao, S. A., "Application of immobilized banana peels (Musa paradisiaca L.) into calcium alginate beads for removal of chromium (VI) from aqueous solution" IJTSRD. Vol.2 (2)2018, p 1310.

[4] Jayakumar,V.;Govindaradjane, $S$,. "Biosorption of Cadmium by Green Algae A Review". J. Adv. Chem. Sci. 3(2),2017, pp 480-484.

[5] Rashid H.M. and Faisal A. A.H. "Removal Of Dissolved Cadmium Ions from Contaminated Wastewater using Raw Scrap Zero-Valent Iron And Zero Valent Aluminum as Locally Available and Inexpensive Sorbent Wastes" IJCPE Vol.(19 No.4) 2018, 39-45.

[6] Puranik, P.R.; Paknikar, K.M., "Biosorption of Lead, Cadmium and Zinc by Citrobacter Strain MCMB Characterization Studies", Biotechnol. Prog. Vol.(15), 1999, pp 228-237.

[7] Ozer, A., Dursun, G., "Removal of Methylene Blue from Aqueous Solution by Dehydrated Wheat Bran Carbon" J. Hazard. Mater, vol.146 (1-2), 2007, pp262269.

[8] Theydan S.K., "Effect of Process Variables, Adsorption Kinetics and Equilibrium Studies of Hexavalent Chromium Removal from Aqueous Solution by Date Seeds and its Activated Carbon by $\mathrm{ZnCl} 2$ " IJCPE Vol.(20No.1) 2019, 23-29.

[9] Aksu Z. "Equilibrium and kinetic modelling of cadmium(II) biosorption by C. vulgaris in a batch system: effect of temperature". Sep Purif Technol.,vol.( 21), 2001, pp. 285-294.

[10] A. F. Ali and Z. T. Abd Ali, "Interaction of Aqueous $\underline{\mathrm{Cu} 2+\text { Ions with Granules of Crushed Concrete", ijcpe, }}$ vol. 20, no. 1, pp. 31-38, Mar. 2019.

[11] Mohammed, A.; Al-Tahmazi, T.; Babatunde, A. O., "Attenuation of metal contamination in landfill leachate by dewatered waterworks sludges." Ecological Engineering, vol. 94 2016, pp656-667.

[12] Foo, K. Y.; Hameed, B. H.,. "Insights into the modeling of adsorption isotherm systems." Chemical Engineering Journal. 156(1) 2010 ,pp 2-10.

[13] Gheju, M.; Miulescu, A., "Sorption Equilibrium of Hexavalent Chromium on Granular Activated Carbon." Chem. Bull. Politechnica Univ. (Timișoara). Vol.52(12), 2008, pp41-46.

[14] Ho, Y. S.; Porter, J. F.; McKay, G., "Equilibrium Isotherm Studies for the sorption of divalent metal ions onto peat: copper, nickel and lead single component systems." Water, Air, and Soil Pollution, vol141(14,)2002, pp 1-33.

[15] Mohan, D.; Pittman, C. U., "Activated Carbons and Low Cost Adsorbents for Remediation of Tri- and Hexavalent Chromium from Water. Journal of Hazardous Materials, vol.137,2006, pp762

[16] Ho, Y.-S.; McKay, G., (1999) "Pseudo-second order model for sorption processes." Process Biochemistry. 34(5), 1999,pp.451-465.

\section{كفاءة الطحالب المقيدة في ازلية الرصاص من المحاليل المائية}

\section{هاله نصيز و عبيز الورد}

جامعة بغداد, قسم الهندسة البيئية

الخلاصة

تهدف هذه الدراسة إلى إظهار فعالية تجميد الكتلة الحيوية (الكلوريلا المجفة الخضراء) في شكل حبة كروية الشكل لإزالة أيونات الرصاص من المحاليل المائية المحضرة مختبريا في معايير تشغيلية مختلفة مثل الرقم

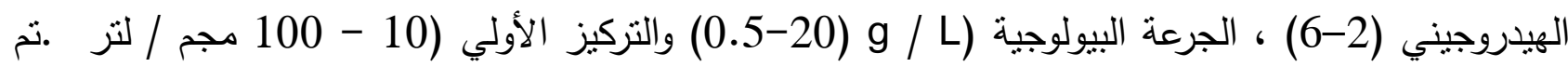
الحصول على كفاءة إزالة بلغت أكثر من 90 \% ومن خلال عمل تحليل FTIR وتحليل المجهرية والاشعة السينية SEM-EDX لكرات الالجنيت المقيدة فيها الطحالب قبل وبعد الامتصاص ظهر الفرق في المجموعات الوظيفية على سطح المادة المازة نتيجة التبادل الايوني الحاصل خلال عملية الازالة. كا تم تطبيق موديلات التوازن ( Freundlich و وكان اكثرها انطباقا مع النتائج موديل (Langmuir) بمعامل الرتباط (0.994) = والموديلات الحركية ( pseudo-first-order و (pseudo-second-order ) كان اكثرها

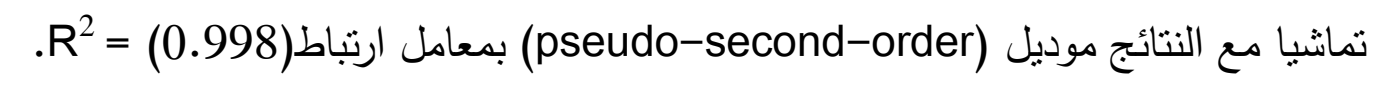
الكلمات الدالة: تقييد، المعادن التقبلة، طحالب الكلوريلا الميته، الامتزاز الحيوي ، موديلات رياضية وحركية 